\title{
The profit as in-company evaluation of the construction site effectiveness
}

\author{
Hubert Anysz ${ }^{1, *}$ \\ ${ }^{1}$ Warsaw University of Technology, Faculty of Civil Engineering, Institute of Building Engineering, \\ Division of Production Engineering and Construction Management, ul. Armii Ludowej 16, 00-637 \\ Warsaw, Poland
}

\begin{abstract}
The paper discuss the profit made by construction sites operated by one company as a measure of their effectiveness. The different types of cost, that should have been covered by income, were described. The distinction between indirect cost made on building site and indirect cost made by headquarter of a company were shown, as well as necessity of including both on them in calculating building site effectiveness. Three different method of assigning company overhead cost to the building site were shown and discussed. Their significant influence on building site profitability was emphasised and calculated for exemplary values. The necessity of calculating full cost for each building site operating by one company was discussed in the article too, by showing which information is necessary for a company management, a building site management and for company shareholders.
\end{abstract}

\section{The profit as a measure of effectiveness}

It can be said, that a given project was successful if planned time schedule was kept and cost was not overrun [1], [6]. The time schedule is easy accessible document. It clearly shows the start and the end of a construction project, so it is easy to check if milestones were kept by a contractor and if the completion date of a project was not later than planned its end. The cost of a project is different for a client and a contractor. When the contract value is a lump sum, a client expects that the total cost of erecting a building object will not exceed the value stated in the contract signed with contractor. In the case of unit prices based contract, the client's expectations allows for some changes in the contract value according to the differences between the quantity take off and real number of works executed. A contractor's point of view on cost of a project is much different. The value stated in the contract signed with a client is an upper limit of the contractor's income that can be achieved on a given project. A cost of the project can be managed and it should be lower than income. It should cover direct cost of construction, indirect cost arisen on site and at the headquarter of a company. Remaining part of income - if appears - constitute profit of a building site.

* Corresponding author: h.anysz@il.pw.edu.pl 


\subsection{The necessity of making profit}

Profit worked out by a company allows for development. New machinery can be acquired, contracts of bigger values can be won and financed. As a result of that higher profit can appears in a company financial statements. A tendency to making profit higher and higher can be explained by safety of a company existence on the market. The significant part of profit usually is not spent, but left in a company as a reserve for crisis time. This is one of the most important reasons for making a profit - willingness to survive [7], [8].

\subsection{Calculating a profit for a company operating only one building site}

Assuming that the company operates only one building site, income achieved on that should cover cost (direct and indirect) and remaining part constitute profit. Fig. 1 shows how income is divided.

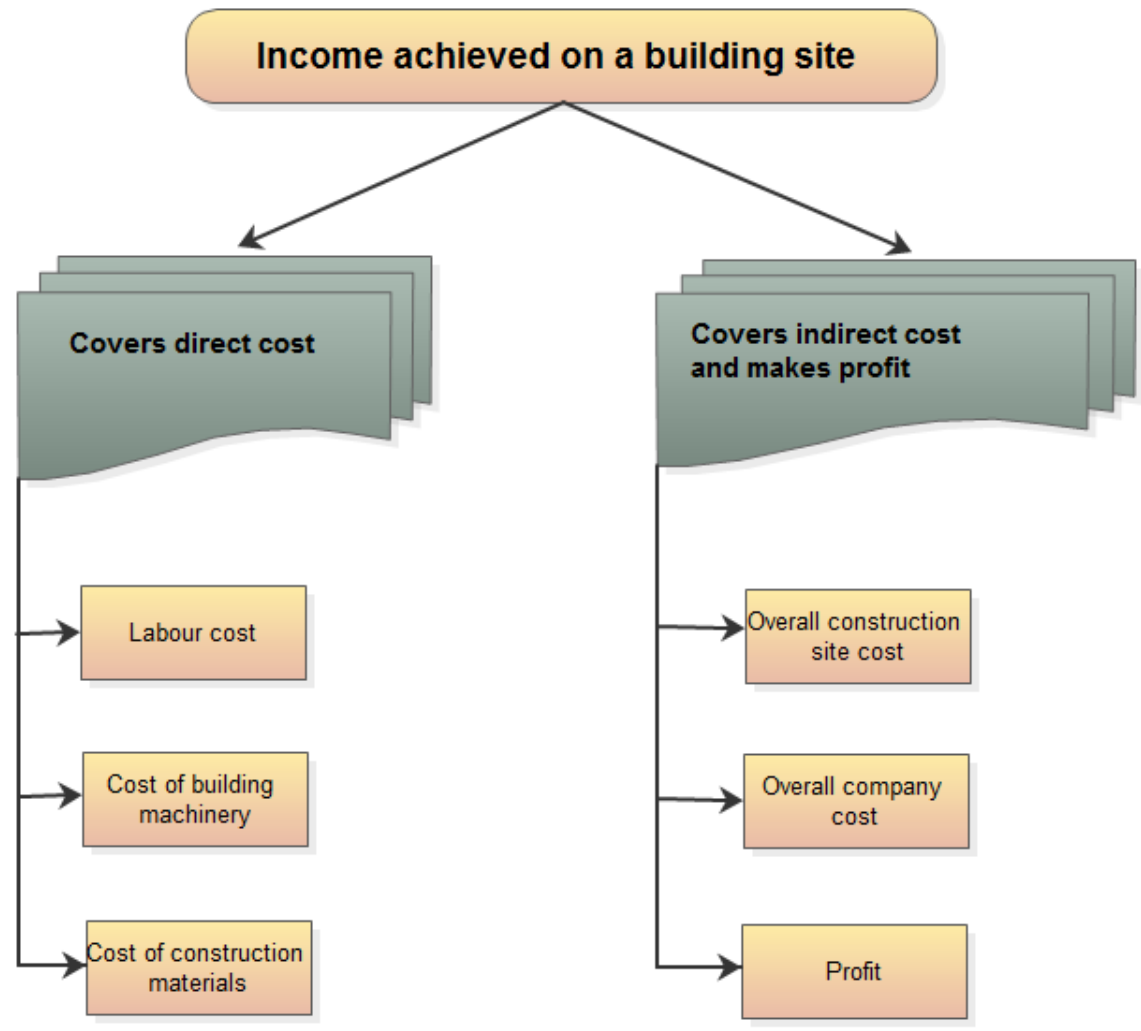

Fig. 1. Division of income achieved on construction site.

Direct cost can be easily assigned to the specific works being carried out. The cost of site management, office and social containers, a fencing, guard service, lightening the site serves to all activities. As the building site is settled as one unit, there is no need to divide these indirect cost to specific activities. Achieved income should cover them all. The company has its headquarter, accounting - department, human resources department etc. 
Their cost should be covered by income too [3], [5]. To calculate the profit of the building site the following formula can be applied

$$
Z=P-T K W-K b
$$

where:

$Z \quad$ - profit of a building site,

$P \quad$ - income achieved on a building site,

$\mathrm{Kb} \quad$ - overall construction site cost,

$T K W$ - $\quad$ direct cost of construction works,

Having $Z$ calculated, the company profit $Z p$ can be calculated too as

$$
Z p=Z-K p
$$

where:

$Z p \quad$ - $\quad$ profit of the comapany (operating only one building site),

Kp - overall company cost.

\subsection{Calculating a profit for a company operating a few building sites}

Profit of the company that operates a few building sites can be calculated on the basis on formula (2) where profits from all building sites should be summarized. Then

$$
Z p=\left(\Sigma Z_{i}\right)-K p
$$

where:

$Z_{i} \quad$ - $\quad$ profit from $i$ building site being operated by the company

In order to calculate profit achieved on each individual building site, it is necessary to assign parts of overall company cost $(\mathrm{Kp})$ to each building site.

\section{Methods of assigning overall company cost to building sites}

\subsection{Methods description}

There is no obligatory method of assigning overall construction cost to building sites in Poland. The decision is left to the CEO (Chief Executive Officer) of the company. He/she can be advised by financials but the decision is carried by CEO [2]. There are some methods widely applied [3], [4]:

- in equal portions,

where:

$$
K p_{i}=K p / n
$$

$K p_{i} \quad$ - $\quad$ the part of overall company cost assign to $i$ construction site,

$n \quad-\quad$ number of building sites operated by the company. 
- proportionally to site income,

where:

$$
K p_{i}=\left(P_{i} /\left(\Sigma P_{i}\right)\right) * K p
$$

$P_{i} \quad-\quad$ income achieved by $i$ construction site

- proportionally to site profit,

$$
K p_{i}=\left(Z_{i} /\left(\Sigma Z_{i}\right)\right) * K p
$$

Having Kpi defined, it is possible to write a formula for profit of the i building site after overall company cost assigned, marked as $Z_{i}{ }^{\prime}$.

$$
Z_{i}^{\prime}=Z_{i}-K p_{i}
$$

CEO can chose method, even propose his/her own one e.g. the ratio 3:7:6:8 for four building sites the company operates. Nevertheless, each method will have different consequences for separate building site.

\subsection{Examples of company overhead cost assignments}

Let's assume that the company operates three building sites A, B and C. The results achieved by each building site are shown in tab. 1, as well as the company profit is calculated. It is to emphasise, that the construction site profit is calculated before $K p$ assignment.

Table 1. Results achieved by building sites and the company

\begin{tabular}{|l|c|c|c|c|}
\hline \multicolumn{1}{|c|}{ Results achieved } & Site A & Site B & Site C & Total \\
\hline Income & 20000 & 5000 & 7000 & 32000 \\
\hline Direct cost & 13400 & 3000 & 4550 & 20950 \\
\hline Overall construction site cost & 6000 & 1500 & 2100 & 9600 \\
\hline Construction site profit ** & 600 & 500 & 350 & 1450 \\
\hline Overall company cost & $*$ & $*$ & $*$ & 1200 \\
\hline Company profit & - & - & - & 250 \\
\hline
\end{tabular}

* not assigned yet $\quad * *$ before $K p$ assignement

Subtraction $K p_{i}$ from the construction site profit, using three described above methods (as shown in tab 2) can give profit or loss for a given building site. The method of assignment does not affect the total profit of a company, of course.

Site B only shows the profit every time, independently from the $K p$ assignment method. Sites $\mathrm{A}$ and $\mathrm{C}$ can be evaluated as profitable or loss making in case on choosing different assignment methods. Which method is the right one, which method is fair. It can not be said. The contract A (the biggest one) was won due to low profit assumed. It has allowed for low bid price. Applying the method where the company's overhead cost are assigned proportionally to income, it puts this building on loss side. The contract $\mathrm{C}$ is middle profitable i.e. $5 \%(350 / 7000)$, but its income is much lower that for contract A. Dividing company overhead cost on equal parts makes loss for Site C. 
Table 2. Building sites profit after assigning company overhead cost

\begin{tabular}{|l|c|c|c|c|}
\hline & \multicolumn{4}{|c|}{ Profit after $\boldsymbol{K p}$ assigning } \\
\hline $\begin{array}{c}\text { Methods of overall company cost } \\
\text { assigning }\end{array}$ & Site A & Site B & Site C & Total \\
\hline Equal portion & 200,00 & 100,00 & $-50,00$ & 250 \\
\hline Proportionally to income & -150.00 & 312,50 & 87,50 & 250 \\
\hline Proportionally to site profit & 103,45 & 86,21 & 60,34 & 250 \\
\hline
\end{tabular}

The contract B is very profitable i.e. $10 \%(500 / 5000)$ and for each method of company overhead cost assigning (chosen from aforementioned) Site B shows profit (varying from 86,21 to 312,5 ). On the other hand assignments are done proportionally to achieved already values. A project manager of contract A can be confused when according to his/her extraordinary engagement, planned profit (before assignment) has risen twice, but according to the assignment method applied, after deducting the part of company overhead cost, the contract he/she managed become much less profitable or even loss making.

Taking a decision about the method of company overhead cost assignment should take into account the assumptions made on the stage of preparing an offer for a given contract the assumed profit level and the total value of an offer. Otherwise assignment of overheads can create false evaluation of building sites profitability.

\section{The reasons of assigning company overhead cost to a building sites}

There are three groups of people interested in proper evaluation of construction sites operated by a given company [6]:

- management of the company,

- building site management,

- shareholders of a company.

All of them in order to carry the right decision, require precise information about profitability of a company and its building sites. In a fact, it is rare case when a construction company operates one building site only. But even then, accounting, human resources, marketing and other functions of a company have to be provided and financed. There is no reason to omit these cost in calculating building site effectiveness. It refers to a company operating more than one building site too.

Owners of a company i.e. shareholders need to be sure that the size of administrative part of a company is matched to the size of a company operations. The total profit of the construction company is not sufficient information to evaluate it. Building site effectiveness is needed. The total profit can be on the satisfying level e.g. according to one, big, very profitable building site only, whereas other sites are poorly managed. In this case the most of headquarter effort is directed to this not profitable sites. Wrongly chosen assignment method can create false, misleading information.

The management of a company should be provided with accurate, precise information concerning building site effectiveness. Directors are responsible for selection of contracts for execution by a company. Proper financial information can help in finding the rules, and to determine which contracts are valuable for a company and which should be avoided. The profit of a building site based on full cost calculation is a measure of project manager abilities and effort too. False evaluation of a building site leads to wrong decisions.

A project manager have to know the system of overhead cost settlements too. $\mathrm{He} / \mathrm{she}$ mustn't be surprised at the end of the project, that the positive financial effect was turned to 
negative by the administrative decision as choosing company overhead cost assignment method is. It is especially important for project managers who are not a company employees, hired for a certain project only.

\section{Conclusions}

Construction company overhead cost are generated by its headquarter. The functions of accounting, human resources, marketing departments etc. as a managerial functions are necessary for operations and have to be financed. The effort of exact assignment of aforementioned cost (of each headquarter department) to the building site would be too high. CEO makes a decision about the method of assigning these overhead cost to a building sites (projects). In order to create proper, precise and reflecting reality information about building site effectiveness, the method should be chosen very carefully, taking into account initial assumptions concerning each project being executed. Wrongly chosen assignment method can radically change the project evaluation. Profitable building site can be shown as a loss making one. Shareholders of a company, top company management and project managers require precise, reflecting reality information about construction project financial effectiveness in order to carry correct, future decisions aimed to making a profit by a company.

\section{References}

1. D. Skorupka, D. Kuchta, Zarzadzanie ryzykiem $w$ projekcie, WSOWL, Wrocław (2012)

2. Ustawa z dn. 29.09.1994 o rachunkowości (2016) - Polish accounting law

3. C. Drury, Management and Cost Accounting, Cengage Learning (2015)

4. ACCA Texbooks. Management Information, AT Foulks Lynch Ltd (1998)

5. B. Kacprzyk, Kosztorysowanie obiektów i robót budowlanych, Polcen Sp. z o.o. (2010)

6. A Guide to the Project Management Body fo Knowledge, Project Management Institute (2000)

7. E. Głodziński, Efektywność ekonomiczna - dylematy definiowania i pomiaru, Zeszyty Naukowe Politechniki Śląskiej, Organizacja i zarządzanie Nr kol. 1919 (2014)

8. R. Borowiecki, Pomiar i ocena procesów kreowania wartości w badaniu efektywności przedsiębiorstwa. Wyd. UE w Krakowie, Kraków (2009) 